\title{
URBAN PLANNING OF NOVI SAD IN THE PERIOD OF POST-SOCIALISM
}

\author{
A B S T R A C T
}

Urban planning in the post-socialism period is presented in this paper through the case study of Novi Sad, the capital of the Autonomous Province of Vojvodina. The research is undertaken in order to understand the image of the city which has changed radically, which is still undergoing transformations, but also in order to understand the role of urban planning in creation of the urban structure in diverse social circumstances. The accent has been placed on the influence of the social changes in the post-socialist period upon the urban planning of Novi Sad. Social changes affect the urban development and the manner of planning and are the cause of the continuous transformation in the way of thinking and planning. Urban transformation under the influence of the social changes is one of the significant planners issues raised in the recent years in the countries undergoing transition. All those changes in urban planning require special prudence and it can be questioned whether undertaking of the more extensive new construction in that period and in the time of diminishing quality was the most advisable undertaking. 


\section{INTRODUCTION}

The transition that ensued following the collapse of the socialistic ideology comprised the development of the market economy, private sector and democracy in the countries in which government/social ownership and political monopoly dominated. The social changes have brought about the changes in the socio-political life, the changes in the present socio-planned economy and economic relations, government institutions, however also the changes in the overall image of the society. This paper will research the transformations in the way of planning consequent to the social changes in the post-socialism period (so-called transition) and the impact of these changes upon the urban transformation of Novi Sad.

The transition process, which started in the 1990s, brought about tremendous changes within the field of the housing construction and dwelling. The resolution of the housing issue was no longer within the public concern, but the problem was transferred to the individual citizen, who solved the housing issue himself, against different forms of the government facilitated aids.

Novi Sad is the example of the city where urbanism, following the collapse of the socialist ideology, was at same time both developed and suppressed. Following urbanism which was developed in "the modern times" under the influence of the Athens Charter, the emergence of the new residential settlements, urban functionalism and zoning, the construction of the detached buildings in the greenery, the traditional urban fabric entered the battle for the urban identity and urban future. In the transition process, due to diverse social and economic circumstances, the inflow of the population due to the war activities, many cities in the region, and so did Novi Sad, were confronted with the issue of massive illegal construction (squatter construction), namely the emergence of the new suburban parts, very often organized in unplanned manner. In Novi Sad which is still undergoing the transition process, recently the suburban parts have been experiencing their transformation, most often under the influence of the clients' requirements against the development of the new typologies of construction, adjusted to the new living conditions.

The study of the social changes in the transition period within the sphere of the urban planning should demonstrate how the urban morphology of Novi Sad has changed, what the quality of the new built environment is, what the relation to the existing morphology environment is and finally what the consequences of such way of thinking are. On the other part, the study should provide the new guidelines in the process of urban reconstruction and plans 
implementation, for the purpose of realizing the new construction entities which would contribute to forming the new identity and at the same time would also contribute to the improvement of the existing morphology of Novi Sad.

\section{URBAN PLANNING OF THE POST-SOCIALIST CITY}

The manner of planning in the capitalistic social systems represents the theoretical framework which is set as the fundament for urban planning in the post-socialism period. The collapse of the socialist social system unambiguously and undeniably indicates to the necessity of building capitalism, however this thesis can be understood as simplified. The key question emerging in that process is which model of capitalism would be applied, namely which model is feasible in reality. The development of capitalism in post-socialist period, often defined as post-socialist transition, has comprised the universal reform of the institutions and a series of the social changes. Urban planning and the related processes in the construction of the environment should be placed within broader public context, whereby they would become more clear and more liable to criticism. Given that the research has been based on the social changes in the post-socialism period, the study of the city and its spatial organization inevitably lies in the understanding of the positive or negative consequences caused by such changes. The social changes in the post-socialism period have also resulted in post-socialism cities becoming administratively, politically and economically more independent, so that they could influence their own development. The introduction of the market has affected the innovations, i.e. the emergence of the new requests and requirements. "It determines the planner actions, like urban reconstruction of the city center, being the place of the most intensive gathering and exchange of information, goods and services. Also, it is closely connected to the requirements of the city expansion, conquering the new spaces and the manner of land acquisition." (Danilović, 2003, 45).

In the centralized systems, which is characteristic for the period of socialism, transforming of the urban space was under control of the city authorities competent for planning by means of urban land use and building codes and regulations. In the transition period the type of stakeholders managing the general urban space transformation has dramatically changed, being the consequence of real estate market liberalization. In that process the retail sector played a significant role by increasing the prices in the commercial sector of the above mentioned market (Nađ, 2005, 364). Transformation of 
the urban spaces progressed in all countries and the cities of the Central and Eastern Europe, although to a different degree, since the national politics, urban planning and the local regulations had a significant role in orientation of the spatial transformation.

During transition, certain urban regions on one part experienced the process of diverse developments along with some losses whereas, on the other part, some regions acquired economic attractiveness. Capital cities and big urban centers have been privileged in that sense, given that they attract a grate share of investments in banking, retail sale and information technologies. The cities of the former Yugoslavia have had a specific transformation when it concerns the post-socialism period. Yugoslavia had a liberal socialist system and its prospects for a successful transformation were the greatest. However, the disintegration of the country and the war have conditioned a slowed transition, with the consequences which are currently visible. Yugoslavia was in the economic and political isolation, therefore in 1990s there did not come to foreign trade liberalization, opening of the country and to integration of the cities into the European city network. It is undisputable that social changes affect the urban development, namely that they are the cause of the continuous transformation in the form of thinking and planning of all urban development segments. However, notwithstanding the visible consequences of the social changes in the post-socialist cities, their influence has particularly been felt in the development and use of the construction land, legislative grounds and implementation of urban planning. The impact of the transition changes upon the transformation of the morphology of Novi Sad is most clearly perceived in the housing activities, being the most significant activity in the development of the society.

\section{THE IMPACTS OF THE URBAN PLANNING IN THE PERIOD OF POST-SOCIALISM UPON THE URBAN TRANSFORMATION OF NOVI SAD}

In the period immediately following the World War Two urban planning of Novi Sad was centralized, as well as the system of funding and the municipal services system. In line with the first five-year plan the construction of the power potentials and traffic infrastructure started along with simultaneous development of the urban documentation. Centralized system of planning was relinquished in the period from 1950 till 1963, when there came to the development of the urbanist institutions and urban planning bureaus, development of the new, the second in order Master plan of Novi Sad, 
establishment of municipal services, dislocation of industry and preparation of the south, north and west zone of the city for housing construction. The method of work and consideration was adopted from at that time developed European countries and there came to formation of the new urban regulations of Novi Sad. In the period since 1963 there has come to the intensive urban and economic development of the city. Planned initiatives which emerged in diverse circumstances were in accordance with the economic and social processes and were carefully studied and realized. In line with that the revisions of the master plans, settlements urban plans, complex reconstruction projects, establishing of the modern city traffic network, bridges and public institutions constructions and similar were made and carried out. "In such system, urban planning assumes the key role in distribution of the urban activities, without the formal limitations resulting from the private interest and property, however, also without the objective information on real advantages of the locations which in the market environment is on synthesis basis presented by the urban rent" (Milić, 1996, 20).

Following the collapse of the socialist system there came to the changes in urban planning caused by unforeseeable development circumstances. With the revision of the Master plan and adoption of the Spatial plan of the Republic of Serbia, Novi Sad acquired a new dimension and the role of macro-regional center within the network of Serbian cities. It was planned as the tourist center of the international and global character of $1^{\text {st }}$ degree, as the traffic center of various forms of traffic, as well as the industrial center and in the highly significant Danube-region zone, as the center of public services, as the power supply center and the center of agriculture development. The goals in the urban development were set taking into consideration the new occurrences and processes. However, even despite the existence of a defined strategy of the city development, prepared and realized plans, contemplations on the possible future development condition, the social changes in the transition period that progressed in Novi Sad have demonstrated that the cities developed in an unexpected and unpredictable way. The events that followed in the country and in the region - the disintegration of the former country, the war in the neighborhood, thousands of refugees - have significantly affected the urban development and urban planning of Novi Sad. Novi Sad has become an example of the city where, following the collapse of the socialist ideology, urbanism was simultaneously developed and suppressed.

With the change of the social and economic systems the entire city parts embarked upon the process of the urban transformation and changed their 
morphology. Dynamic residential buildings construction could be realized if with the urbanist parameters the economic conditions acceptable for the investors are provided. "Urban plans, regulations, standards and other mechanisms of regulation defining the use of the space (land and buildings) and the conditions of construction and forming, determine the characteristics of physical structures, their type, functional arrangement, etc. Thus these normative solutions, together with other intervention mechanisms affect the individual location, investment, builders and users decisions and behavior at the space market." (Milić, 1996, 13). Thereby, the social and economic conditions in which the construction progressed had also to be taken into consideration, given that they determined the purchasing power of the average potential real estate buyer.

In the transition process, due to diverse social and economic circumstances, the inflow of population resulting from war operations, many cities in the region, and Novi Sad as well, were faced with the problem of mass illegal construction (squatter construction), namely the emergence of the new suburban parts, often organized in an unplanned manner. In Novi Sad, which is still undergoing the transition process, recently the suburban parts have experienced their transformation, most often under the influence of the clients' requirements along with the development of new typologies of construction, adjusted to the new conditions of living.

The Relation of the Social Circumstances in the PostSocialism Period and Urban Planning of Novi Sad

Plan documentation in Novi Sad in the past fifty years was prepared by an institution, currently known as Public company "Urbanizam" (Urbanism) The Town Planning Institute Novi Sad. In the period defined as transition, planning in Novi Sad acquired a new role, being to enable, apart from the government, involvement of also other stakeholders interested in the development and construction of the city. In the social and economic confusion often called "transition" there came to the changes also in the important urban parameters, first of all in the ownership of the land and introduction of the market and market competition. However, unlike the capitalist regulated systems, with the liberal political and economic tradition, still the broadest public, which is sensitive to the changes in space the most, still had no significant role in governance of the planning process and evaluation of the planned solutions. The participation of the public, pursuant to the valid Law on Planning and Construction, is reflected in organization of the public insight following the 
planned control by the competent Commission for the plans of the local selfgovernment unit, with the possibility of providing remarks or suggestions, on which again the competent Commission for plans will decide. The changed social circumstances are also reflected in the demographic indicators. According to the census of 1991, there were 179,626 residents in Novi Sad. After 1990, certain social, political and economic conditions brought about tremendous transformations in demography, which the previous Master plans could not have envisaged. The city, due to the war conflicts in the regions of the former Yugoslavia, was populated by the refugees from the war-engulfed regions. The second reason of the demographic growth is the result of the transition process and the growth of the economic activities and employment. With the unplanned increase in the number of population ${ }^{1}$ there came to the new processes in the city, changes in its morphology, particularly in the underdeveloped parts, most often with illegal construction and without clear and precise spatial articulation.

The city, its government, the institutions and the citizens have been faced with the economic, social and environmental transformation of certain parts of the city. In compliance with the Laws on Planning and Construction, which were promulgated also for the purpose of institutional activities of solving these issues, the zoning plans were prepared, and legalization of illegally constructed buildings was made possible, under certain conditions. Except for forming the squatter settlements with one-family residential buildings, the increase in demand in real estate within multi-family structures was also affected by the increase of population, which has fostered hyper-construction of these buildings within traditional urban structures, and with it also preparation of the new detailed regulatory plans, in accordance with the social changes in the transition period.

Along with the social changes in Novi Sad, the preferences of the population changed, and the direct result is the increase in demand in land and real estate. At the same time there came to significant structural changes, which are manifested through construction of the new and reconstruction, revitalization and rehabilitation of the existing real estate. It is a generally concurred evaluation that the real estate market in the countries undergoing transition is more unstable and susceptible to diverse influences. The inadequacy of the society to the changes ensuing with the appearance of transition have produced the consequences upon the city urban development. Following the demographic changes, urban planning has become an activity the priority 
of which becomes resolving the insufficient housing stock, however the existing legal framework and the institutions have not been able to prevent the degradation of space.

The changes within the framework of the housing activities, caused by the introduction of market and by demographic changes in the city, as well as the changes in carrying out the economic activities, the increase of the interest in commercial and catering activities, were one of the key reasons which brought about the corrections of many planning decisions from the earlier period, as well as the legal and by-law urban documents at the level of the city and the republic.

The Influence of the Changes in Housing Activity upon the Urban Planning of Novi Sad

In the period of socialism dwelling was the objective of any construction. After the political system in post-socialist countries had changed, there came to the changes of the planned economy into market orientated one. The system of dwelling and housing policy in Novi Sad, due to the reforms in other fields, has experienced tremendous changes since 1990. Following the decline in the number of the newly constructed flats, there came to privatization of the government-owned flats in the first half of 1990s. In comparison to the European Union countries having many-years'-long tradition of housing markets and market regulations, the housing market in the transitional countries were only under development. The demand in the flats in the transition period was increasing, which after a certain period of dormancy of construction and privatization of the government-owned flats, fostered the construction of the new multi-family residential buildings, which are placed at the market. However, in adjusting the housing policy to the new conditions, the absence of the system of social character dwelling was evident, which mostly affected the socially handicapped population.

The land policy is extremely important for the housing construction. The condition for the efficient realization of housing construction and the construction of the corresponding infrastructure is the active planning and land governance policy. The system of urban planning in Serbia is postulated in a pyramidal form, from the higher rank plans (spatial plans, master plans) to the detailed elaboration plans (master regulatory plans, detailed regulatory plans, urban designs), whereby the fundamental principle is that the lower rank plans have to be harmonized with the higher rank plans. 
The determined development concept has not changed, however, certain social changes in the transition period impacted significantly urban development, which can already be identified and perceived today. Introduction of the market into housing activity, privatization of the banking systems and securing financing of dwelling through mortgage loans, changes in the demographic structure, increase in number of population, as well as the increase of the share of single households, all required the new housing policy in urban planning. In Novi Sad it has conditioned adjustment to new manifestations, preparation of the new plans of detailed elaboration and reassessment of the valid planned solutions. The real estate market and greater demand in flats in the last five years of transition were significantly affected by the sudden inflow of money due to privatization of some more significant companies in the neighborhood of Novi Sad, but also by a sumptuous inflow of money to the real estate market in Novi Sad due to sale of the real estate in the neighboring countries. The greatest amount of accumulated funds, which the individuals acquired in diverse ways, was streamlined to the housing construction in the region of Novi Sad, where there existed great demand in flats, and thus investment was profitable.

At the beginning of the social changes in the transition period, the scope of housing construction in Novi Sad dropped below the many-years' long average from the previous period, which amounted between one thousand and one thousand five hundred flats annually. At that time in Novi Sad there came to great increase in illegal construction (squatter construction), resulting from the great inflow of the refugees population, however, other causes of the emergence of illegal construction in that period cannot be neglected either (grey economy, war profiteering, inefficiency, namely the tacit consent of the state which thus maintained the social peace and others). The illegal construction in the nineties of the last century, and the increase of the housing

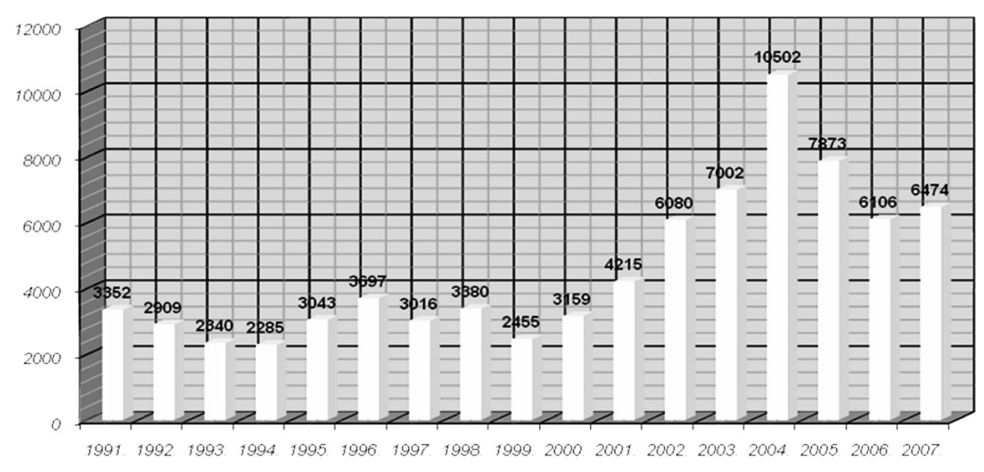

Figure 1 Examples of urban and spatial plans in Romania. 
construction in the period since 2002, have significantly affected the urban planning of Novi Sad, however, have also left behind the consequences upon the dwelling, housing construction and spatial development of Novi Sad.

By studying the total number of requests in the period since 1991., until present (Figure 1), it can be determined that in the nineties the average number of the requests received was only approximately 3000 requests per annum and that following that period the number of request gradually increased, in order to reach the figure of 10502 requests per annum in 2004. Significant increase of requests for issuing of the urban permit, building permits and the opinion in the procedure of legalization resulted, first of all, from the activities of the city administration for urbanism and housing affairs in the procedure of legalization of illegally constructed buildings at the territory of the city, engagement of the building inspection of the city of Novi Sad in suppression of illegal construction and speeded up city construction. Following 2004., the number of requests submitted has decreased gradually so that in the last three years this parameter amounted to approximately 6200 requests per annum (Jevtić, Grujić, Nejgebauer, 2010, 105). It has been confirmed by the City Administration for Urbanism and Housing Affairs in Novi Sad, that in the procedure of submission of request for legalization, pursuant to the provisions of the valid Law on Planning and Construction, there were 27000 requests submitted. This fact indicates that the trend in the number of requests at the annual level will not decrease in the coming period.

The number of flats built in the period from 1945 till 2008 was in accordance with the dynamics of requests submitted for the construction of the multifamily residential buildings. In the period covering fifty-five years (19452000), the total number of the flats built in Novi Sad amounted to 49510. In the period from 2000 to 2008 , the approval was granted for the construction

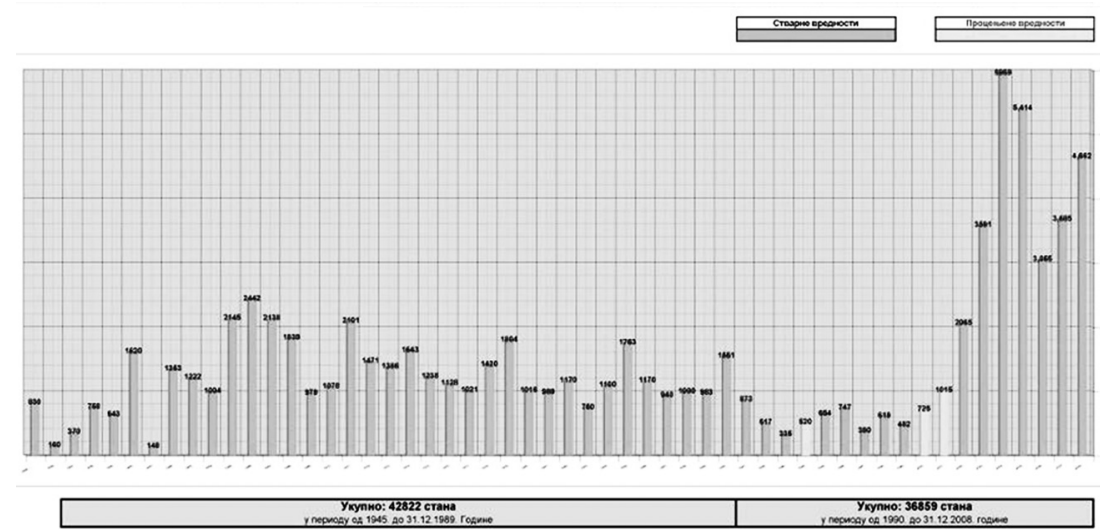

Figure 2 Examples of urban and spatial plans in Romania. 
of 36134 flats, representing a significant indicator, given that in those nine years $73 \%$ of the total number of flats constructed in the period from 1945 to 2000 was constructed. The greatest value was achieved during 2004, when in the procedure of issuing urban approvals to the project documentation the approval was granted for the construction of 5959 residential units (Figure 2).

Following 2004 the decline in the number of requests submitted is noticeable, and such trend persisted also due to the consequences of the global economic crisis of 2009. These data indicate the fact that a great portion of accumulated funds, which the individuals acquired as per diverse bases (privatization, grey economy, foreign capital and other), was placed in Novi Sad following 2000 , in which the real estate prices were increased, and at the same time there existed the possibility of real estate renting, and thus there was greater economic interest in investment in these regions. Significant portion of those funds was directed to the housing construction in the region of Novi Sad, where there was a great demand in flast, and thus the investment in them proved to be profitable.

The analysis of the impacts of changes in housing activity upon urban planning of Novi Sad has indicated that dwelling has a significant role in all social systems and that it significantly impacts the social, economic and cultural development of a city. The changes comprising the establishment of the more efficient, market system of economic activities, the reform of banking system, re-structuring of the large state-owned companies, privatization and similar affected the development of the housing market and it was to a great respect reflected also on the urban development of the city. Unlike the mass production of the flats in the period of socialism in aspiration of achieving the social goals, in the period of transition, the entrepreneurs, the sole goal of whom was the profit, became a new social group in the process of urban development. The effect upon the urban planning is reflected in introduction of the dynamic planning procedures, adaptation to the new conditions and stakeholders when preparing plan regulations and fostering of the urban renewal of the traditional city zones. However, due to unclearly defined socio-economic framework of transition and disinclination to the social changes, the hyper-construction without a clear and universal vision of all stakeholders on the strategy of the urban development in that period did not prove a thoughtful move.

The changes in the housing and business and commercial/retail activities in the period of transition resulted in the changes in organization of both traditional and suburban city areas. Due to the unstable socio-political-economic system, 
the changes which occurred in the space brought about the improvement, however much failures. In order to make up for the "lost" years of transition, the city spaces were transformed in haste. Due to the fact that the plans from the period of socialism, because of the occurred social changes, have become unusable, there originated a new generation of plans, which on one part, marked the reversal to the traditional planning and rehabilitation of the existing condition, and on the other part, enabled investment type urbanism, by lowering the former urban standards. The urban plans attempted at adjusting themselves to the social transformations, to the new conditions and stakeholders, however, different individual influences and interests, diverse social circumstance, non-definition of the public or general interests have affected their rationality and creativity, and with it also the urban transformation.

The Consequences of the Urban Planning in the Period of Post-Socialism upon the Urban Transformation of the Traditional Urban Spaces of Novi Sad

The effect of the social changes in the period of transition upon the urban planning of Novi Sad is mostly perceived through the process of the urban transformation of the traditional urban spaces (Figure 3). Urban transformation is a part of permanent city changes, the conceptual fundament of its survival and its future. With planning the urban renewal and reconstruction the traditional urban spaces of Novi Sad joined in the battle for the new identity, and the integrated functions and activities became a new message, which is readable in the new plans.

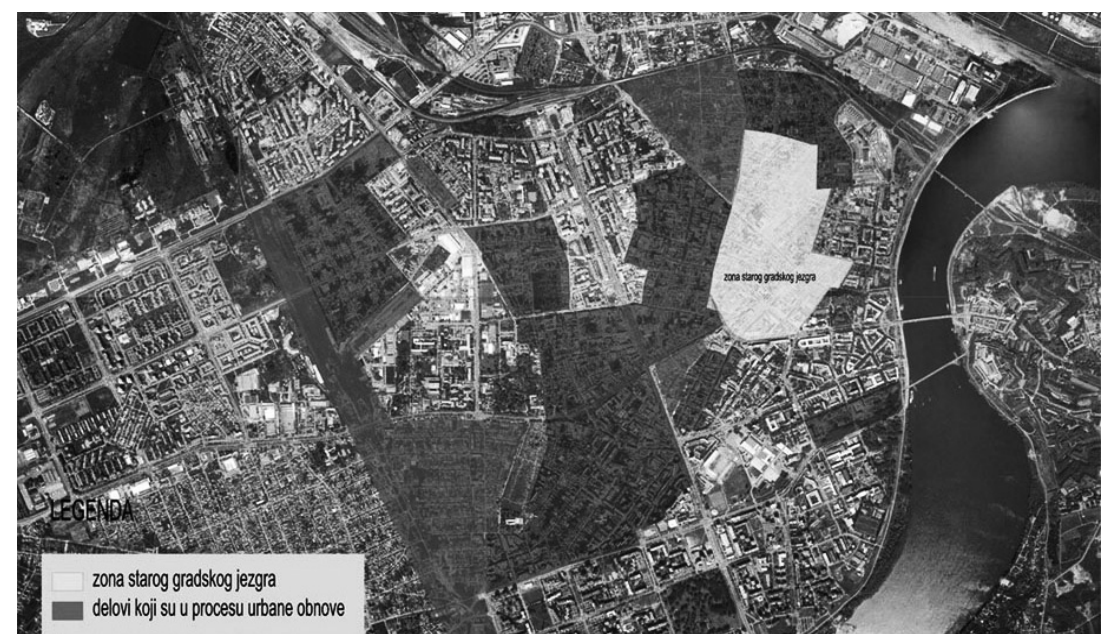

Figure 3 Urban transformation zone in Novi Sad 
Urban reconstruction comprises also the destruction of the existing building and erection of the new one. That means that there comes to the change in intensity of use and most often, to the change of the given urban land parcel use.

Urban transformation of the traditional urban spaces of Novi Sad in the transition period was developed and has been developing in extremely grave economic and political conditions. Urban transformation is not understood as a systematic social action. The development of human requirements and the development of the science and technology, the two most essential reasons due to which the cities are in the state of continuous transformation - quiet or tumultuous one. The changes have inevitably caused also the changes in comprehension of the city, its role, morphology, spirit and character. At the same time, there came to the change in scale of values, where the economic logics and civic values, for decades suppressed, started again to gain in significance with the visible effect upon planning and development of the city, where the urban renewal should acquire cultural, social and economic priority. These changes are the consequences of the general and progressively faster changes of the way of living which change the conditions of the spatial organization and morphology of the cities.

If transition is understood as the process of social changes which occur at any moment, of unequal intensity and unequal forms with long-term consequences, then this research seems justified for the impact of social changes upon urban transformation. Novi Sad has proved as an example of the city in which social changes can clearly be perceived, both in the period following the World War Two, and also in the transition period. After the disappearance of the large state-owned construction companies, Novi Sad was facing a short interruption in the housing construction, to be followed thereafter by a period of "urban construction flourishing". And all that was accompanied by the socalled "market urbanism".

"The Master urban plan of the city of Novi Sad", passed in 1985, envisaged that besides the planned Mišeluk district, given that the vacant capacities were gradually becoming exhausted (Liman, Bistrica districts), a more significant reconstruction of the built parts of the city should be initiated, by changing the type of dwelling from one-family into multi-family dwelling and greater densities, within the regimes of complete and permanent reconstruction, which comprised the replacement of the existing, mostly poor housing stock in order to upgrade the standard of living and increase the rationality of the 
space use." (Jevtić, Grujić, Nejgebauer, 2009, 100). Developing this concept of the Mater plan, Novi Sad readily welcomed the social changes which occurred in the transition period, and with the amendments and supplements of the Master urban plan of 1994, Master plan of 2000, and the amendments of 2006, no deviations from this solution have been made.

In the past the residents of Novi Sad were recognized and identified by the part of the city they lived in. Urban transformation, which has started to develop since the beginning of the nineties of the last century in traditional urban spaces, brought about the loss of the traditional identity of certain parts of the city, mainly due to providing similar or same urban parameters in plan documentation, but also due to the insufficiently thoughtful/duly considered architecture by the design architects and investors.

However, departing from the socialistic way of thinking in urban planning, in their lack of authority and power and being unprepared for these changes, it was not rare that the cities in Serbia were thrown into "the vices of the market of newly composed "rich persons" / "nouveau riche", and their "squatter construction", as if the city was their own private property and the source of fantastic funds available only to them" (Elin, 2004, 11). Urbanization has progressed, and the changes in the urban development were more and more visible. The development and the tumultuous changes occurring in the recent twenty years, inclusive of the almighty power of capital, even despite the positive changes in thinking and manner of urban planning, resulted in the crisis of the urban phenomenon when referring to the measurability of the quality of urban living: the economic, political, environmental, sociological and urban ones.

Urban Transformation of the Traditional Residential Zones of the City

Commitment that the understanding of the impact of the social changes is perceived through the relation of the urban processes and transition is clearly expressed in the study of the consequences of the urban planning upon urban transformation of the traditional residential zones. In order to understand this process, it did not suffice to study the process of origination of the new forms, but also to study the causes and consequences of deserting the fundamentals on which the hitherto present social system was based. Like in the majority of the socialist cites, as presented in the theoretical postulates of this paper, in the times of the socialist social relations, transformations of certain parts of Novi 
Sad (Liman 1 being the example) progressed by expropriation and payment of so-called "fair remuneration' for the buildings in private ownership which were destroyed in order to construct multi-families residential buildings. In such conditions, the owner of the house on the land intended for reconstruction, had to accept the offered money amount, or to instigate the court procedure, but could not stop the construction at that land. Thus the legal grounds were established that certain area planed for reconstruction would be realized in continuity.

Following the change of the social system and introduction of the market relations in functioning of the economy, the reconstruction of the parts with poor quality housing stock progressed on the market grounds, namely buying up of the existing residential and other buildings could be realized providing the buildings owners and the client in charge of the construction of the multifamilies buildings on that parcel, would reach a common interest. That means that in the conditions of the market economy, the parameter which have by the urban plan been defined for a certain part, which is planned for reconstruction (construction index and other) directs the potential investors to a great extent to make the decision to build on that location, namely on the concrete parcel. (Krišanović, 2010, 23).

Enacting of the new Laws on Planning and Construction has obligated the institutions, which prepare the plan documentation, to harmonize all valid plans with the legal regulations as well. Even though covered by the plan documentation, namely to a greatest extent by the construction against the issued urban documentation, the newly constructed multi-family residential buildings were often accompanied by the poor quality of architecture and construction standards.

Urban transformation of traditional residential zones progressed to the greatest percentage in accordance with the plan documentation. The above mentioned changes in the housing activity and their effect upon the urban planning were analyzed in the area covering the blocks between Đorđa Servickog, Atanasija Gereckog, cara Dušana and Bulevar cara Lazara streets (Figures 4 and 5). That space is fully intended for the construction of the multi-family residential buildings, by changing the use of the construction land from single-family dwelling into multi-family one. The aerial photograph of 1998., shows the final phase of the urban transformation. The selected urban fragments represent a model example by means of which transformation in other city zones can be explained, and which comprised the change of the use of one-family dwelling into multi-family dwelling. 
Spatial organization was based on the elements defined by the Master plan, as well as on the commenced realization of the existing plan documents. The fundamental concept comprised the complete reconstruction of the existing ground-floor family residential buildings, while preserving the basic street network. Adopting the morphology (physical structures) which originated by implementation of the previous plans, the concept of adaptation of the future structures to the existing ones has been elaborated. The rows of buildings of multi-family dwelling, having GF+2+Attic $-\mathrm{GF}+5+$ Attic storeys, along with initiation of forming and materialization which would form a harmonious spatial entity have been planned. ${ }^{2}$

The favorable starting presumptions, which were essential in providing the dynamic process of transformation of the analyzed space, have been realized by corresponding storey levels of the buildings, namely the morphology of space meeting the economic standards has been established. Thus the construction of the flats according to the market acceptable prices within certain socio-economic conditions has been made possible. The flats market price, besides construction costs, was also affected by other factors, such as location, distance from the center, demand, parking spaces provided and similar. The building construction dynamics has also conditioned the municipal services development and building of the traffic infrastructure within shortest possible term, which had an impact upon the favorable living conditions.

With the analysis of this space, one arrives to the conclusion that intensive construction which has been present since the nineties of the last century, culminating in 2004, produced a series of significant changes in the space and its use. The image of certain parts of the city (Grbavica, Detelinara, the area around Bulevar oslobođenja, etc) have been fully changed, where the poor building stock has almost fully been replaced, and the market offered with a great number of flats at reasonable prices. In traditional residential districts of the city, in which the reconstruction has been planned by plan documentation, however with smaller number of storey level and small scale morphology, namely with the urban parameters on the basis of which the client cannot construct the flats of the standard quality at the market acceptable prices, transformation will progress by replacement of the individual buildings (at locations where the economic parameters are acceptable), and within a longer time period. Such locations in the districts of Novi Sad, known under the names Almaški kraj and Podbara, are situated in the immediate vicinity of the old urban core, and thus besides the reconstruction and transformation of the morphology by changing the use form one-family dwelling into multi-family 
dwelling of smaller number of storey levels there are also districts in which it is mandatory to preserve the ambience characteristics (the legacy of urban street grid, regulations, storey levels, use, etc).

Due to the emergence of the same or similar forms of the buildings in different districts of the city, many traditional districts of the city in the process of urban transformation have lost a doze of identity and identifiability. Even despite the meaningful plans adjusted to the new conditions, there came to hyper-construction of the multi-family buildings, the improvisations of the investors and impossibility of institutional governance of the entire construction process, the consequences of which in the aesthetic and public sense are currently perceivable.

\section{Urban Transformation of Suburban Districts of the City of Novi Sad}

The terms "periphery", "Suburban districts" and "outskirts" today represent the synonyms for the reduced growth of the cities of unfathomable boundaries and complex, but also non-uniform forms and processes. During the last century the erected up to the level of global phenomenon, peripheral urban structures, first of all the residential ones, in the previous epochs had different and positive connotations. The expansion of the city, the old peripheral structures become integrated with the existing urban cores and the characteristics of periphery is lost. Urban peripheries are today perceived also as the independent categories which besides dwelling also have other activities and functions and represent a significant part of the city functioning. In the transition process, due to the diverse social and economic circumstances, the inflow of population due to war activities, many cities in the region, particularly the metropolitan centers were faced with the problem of mass illegal construction, namely with the emergence of the new suburban districts, often organized in an unplanned manner.

By forming these districts, most often at the agricultural land adjacent to the peripheral districts, there came to the integration of at that time existing peripheries into the urban morphology (Figure 6). However, notwithstanding the global economic and social changes and different approach to periphery development, suburban districts of the cities in the transition countries most often preserved the traditional forms and typologies, and they primarily related to the family residential buildings. 
Figure 4 Ortho-photography dated 1998

Figure 5 Ortho-photography dated 2009
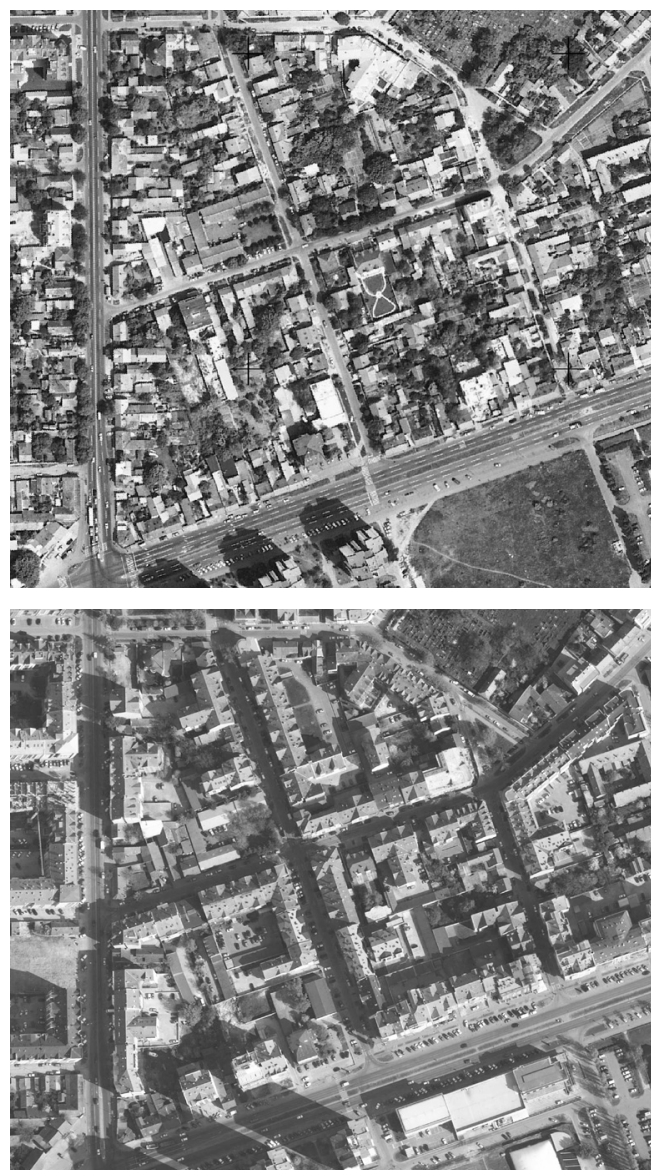

Figure 6

The integration of the former and New suburban parts:

the new settlement and Veternik, 2009

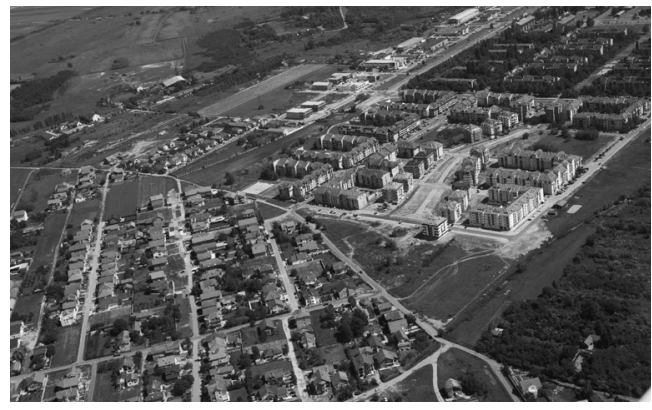

Figure 7

Residential zones of "the new elite

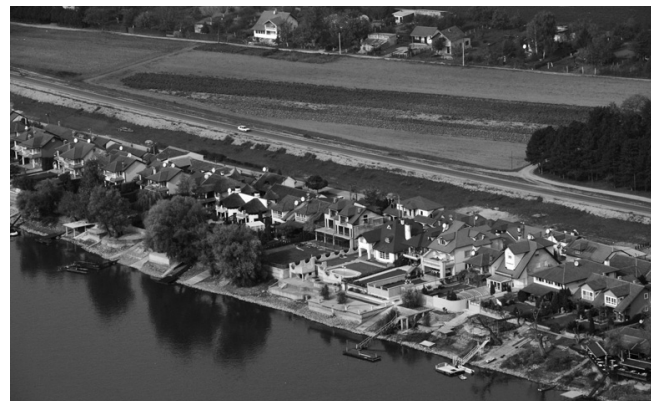


Like in other cities of the region, the peripheral parts of Novi Sad had diverse forms of construction, from the initial workers' settlements, to the development of the new spatial and functional relations through typology of multi-family buildings (the new settlement Bistrica, Liman), to back steppingto the traditional housing types of single-family dwelling (Telep, in the 1980s) as well as forming of squatter settlements due to great inflow of population from the war-engulfed regions (Adice, Veternička rampa, Mali Beograd-veliki rit and similar). Following the World War Two, in the cities in the region at then periphery districts of the city new functional and spatial patterns formed, with the predominant typology of multi-family dwelling. The bordering parts have become contemporary and convenient for dwelling, however their biggest criticism was their mono-functionality.

The new suburban parts, which emerged in the 1990s, due most often to the inflow of population, were to the greatest extent illegally and unplanned constructed for which reason the characteristics of the suburban city parts in Serbia most frequently are: the absence of greenery, endangered pedestrians, squatter construction and unplanned construction, lack of diverse activities, existence of one typology of dwelling (family residential building on the parcel). Negative consequences of the squatter construction in Novi Sad were expressed through: occupancy of the agricultural areas in its neighborhood, degradation and devastation of the natural values, construction on the public interest areas, construction of the settlements without related social standard buildings, increase of the city functioning costs, disturbance of the concept of rational development and others. Although constructed without the valid documentation, the new suburban areas of Novi Sad have developed in accordance with the existing morphology of the parcels, which were internally parceled, taking care to leave the space for the future corresponding infrastructure, which presently has mainly been implemented in these parts of the city (traffic routes, gas, water, electricity).

The new formed "elite" aspired towards the socio-spatial labeling, construction of the family houses, villas or palaces, strikingly attracting notice (Figure 7). At the very beginning of transition, this labeling occurred in the areas of the city which traditionally showed off the social reputation. With the urban transformation of the urban fabric, by means of which the zones of the family dwelling were converted into the collective dwelling zones, the new areas, until then non-constructed become the residential zones of "the new elite". According to Pušić $(2009,157)$ the area of the Danube bank, the week-end settlement Kamenjar, by enclosing itself into the villas yards, mocking the 
concept on the bank as the public spirit, became the victim of the wrongly comprehended transition and the notion of the public spirit. Recently in Novi Sad there has emerged a new type of residential peripheral settlements, being the reflection of the actual social changes. These are the "fenced settlements intended for the use of elite dwelling, which represent a specific spatial expression of the new from of social segregation organization in our environment (two such settlements were constructed at the periphery of Novi Sad - Lipov Gaj and Sunčani breg)" (Kostreš, 2007, 61)

The concept of the model of Novi Sad growth which was manifested by development of suburban parts of the city, in the period preceding transition aspired to be in harmony with the concept of the sustainable development. The spaces were developed in a planned manner, were well equipped in terms of infrastructure, and solved the social, environmental and economic requirements. Suburban parts were well connected by traffic to the existing city structures. By corresponding planning and routing the traffic networks and public transportation it was made possible for the public traffic to develop as the form of transportation in the city and as the alternative to the individual passenger traffic.

Squatter (illegal) construction is the theme requiring much more exhaustive and detailed study Within the context of this study, the conclusion may be drawn that the social changes in the transition period impacted the emergence of the illegal informal settlements. The causes which fostered such manifestation were: inflexible and outdated system and concept of planning, inadaptability to the transition trends and the impact of the market economy, settling of the refugees and displaced population from the war-engulfed regions, unemployment and poverty caused by social transformations, unsuccessful control or tolerating the unplanned construction, voluminous and expensive procedures for obtaining the urban and building permits and absence of the housing policy and strategy. Apart from legalization, more serious directions in regeneration of squatter settlements have to be undertaken by the state and local government, however also in the approach to the planning practice to date, in order to prevent the new emergence of illegal construction.

\section{CONCLUSION}

In the period between he two World Wars the urban development of Novi Sad progressed in accordance with the civic prosperity. Today, also, the urban entities which emerged during that period represent its sacrosanct values. 
Planning, designing, construction and functioning of Novi Sad since the end of the World War Two until entering the transition period has had a type of "governed development". It was the period of self-management socialism, when in line with the new social patterns, it was insisted on discontinuation with tradition within the framework of the new urban policy. The ideology of the progressionist prosperity comprised urbanization, industrialization and the new urbanism. The Master urban plans, which enabled perception of the urban spaces, were the main instrument of city development orientation. Pušić $(2009,185)$ added that not only the boundaries of the construction reyon area were that legal sacrosanct aspect within which the city happened, but together with the urbanists the entire service of public, municipal, inspection and other services functioned.

During the self-management socialism, the standards of urban planning and designing, their urban parameters for certain parts or entities of Novi Sad were conditioned for the purpose of providing a qualitative life of the citizens. The urban development of the city was accompanied by the construction of the municipal infrastructure, parking places, "green areas", children playgrounds and regulation traces were respected to the maximum. The comprehensive interest (the interest of the society as a whole) was deemed the fundamental value of the society, and thus in accordance with that fact the spatial conditions for realization of the institutions and activities of common interest, schools, kindergartens, hospitals, social institutions and others were provided. Cutting Bulevar oslobođenja through the old urban grid was justified by the comprehensive interests, and given the monopoly in planning, there was no room for differentiated consideration of this move. Urban revitalization within the framework of the old city core was carefully considered, following which by setting relatively rigid architectural-urban codes the devastation of this space was prevented. The process of functional urbanism was mirrored in the mass construction of the residential buildings at the non-built spaces of Liman and Novo naselje, with wide streets and avenues. During the time of socialism, the emergence of squatter construction developed in two waves, first by mass conversion of the auxiliary rooms into dwelling rooms due to the increased industrialization and insufficient dwelling spaces, and then due to accumulation of the citizens' funds, who were granted socially-owned flats, and the surplus of the funds was invested in the rest and recreation buildings.

With the social changes at the beginning of the nineties and by narrowminded comprehension of transition exclusively in the economic sense, the comprehensive interests started losing their significance. Capital has become 
the fundamental promoter of the new urban development of Novi Sad, and the land the city resource on which the money turnover took place. That thriving of the market urbanism was interpreted in different ways, from prosperity, emergence of the liberal economy, to the reflection of the disintegrated society. There happened the urban transformation of the city traditional zones, which comprised replacement of the housing stock that has seen better days, mostly the individual family buildings, with the collective residential buildings. In the transition period in Novi Sad, the phase three of the illegal construction happened, mainly in the suburban city parts, which was the consequence of the events in the countries of former Yugoslavia and the increased inflow of population. In the recent years the suburban parts have become the places in which new urban typologies developed, the places for dwelling of the new social "elite".

Within the urban planning of Novi Sad, urban transformation was the concept which has been under development since the period of self-management socialism. It comprised in certain parts of the city the change of the use of the family dwelling zones into the zones of multi-family or common city center, along with gradual replacement of the buildings. Under the influence of these changes, as well as due to enactment of the new legal acts within the field of urban planning, there came to adjustment, amendments and supplements however, also to development of the new planned solutions, in line with the guidelines from the Master plan. However, although planned solutions were meaningful and justified, the entire process of urban transformation lacked the concept of how to realize that. Due to the absence of the clear concept, there came to hyper-construction of multi-family buildings, the improvisations of the clients, the emergence of so-called "atomized urbanism" and impossibility of the institutional governance of the entire process. The relation between the public and the private interest was disrupted, and with urban transformation Novi Sad was simultaneously developed and suppressed.

The study of the impact of the social changes in the period of post-socialism upon the urban planning of Novi Sad demonstrated that the urban development of the city to a great extent depended on the processes which were socially determined. Each change of the society causes the changes in the urban structure as well. It is necessary, following the transition, to create a new meaningful image, to form the identifiable spatial move and on the other hand to follow the changes of the contemporary epoch in a flexible manner, which requires also the new methods of planning and methods of work with the investors and the clients. Along with all tradition and the vast experience 
possessed by the Town Planning Institute of Novi Sad, it could be concluded that in the future the biggest challenge for that institution both in the professional and organizational sense would be the question regarding how to survive on the market and meet the requirements of the ordering party, and at the same time preserve the high level of planner practice in generating the urban space to the benefit of all residents of Novi Sad.

Urban planning should remain the measure which would establish the relations in space and suppress the negative consequences. It is necessary to change the understanding of planning by introduction of the concept of reality and flexibility, rationality and efficiency. The new form of planning, as the activity of special interest for the society and the activity, which the city would understand as the living, dynamic, open and changeable structure, should be prepared for the changes, to presuppose the interventions which would activate the spaces when the changes occur, namely to develop the mechanism which would enable it to accumulate all envisaged and unpredicted changes for the purpose of urban development. 
Figure 1 Public company "Urbanism” Town Planning Institute of Novi Sad, 2008

Figure 2 Public company "Urbanism” Town Planning Institute of Novi Sad, 2008

Figure 3 Public company "Urbanism” Town Planning Institute of Novi Sad, 2009

Figure $4 \quad$ Public company "Urbanism” Town Planning Institute of Novi Sad, 2009

Figure 5 Public company "Urbanism” Town Planning Institute of Novi Sad, 20098

Figure 6 Public company "Urbanism” Town Planning Institute of Novi Sad, 2010

Figure 7 Public company "Urbanism” Town Planning Institute of Novi Sad, 2010 
Andrusz, D.Gregory, Harloe, Michael, Szelényi, Iván: eds.: Cities after socialism: urban and regional change and conflict in post-socialist societies, Blackwell Publishers Inc., Oxford, 1996.

Vujović, Sreten and Petrović, Mina: urednici, Urbana sociologija, editors (Urban Sociology), Zavod za izdavanje udžbenika i nastavna sredstva, Beograd, 2005.

Vujošević, Miodrag: Planiranje u postsocijalističkoj političkoj i ekonomskoj tranziciji, Beograd, Institut za arhitekturu i urbanizam Srbije, 2003.

Vujošević, Miodrag: Novije promene u teoriji i praksi planiranja na zapadu i njihove pouke za planiranje u Srbiji / Jugoslaviji, Institut za arhitekturu i urbanizam Srbije, Beograd, 2002. Ekonomska misao 37.1-2 (2004): 140-142.

Danilović, Nataša: Građevinsko zemljište u procesu tranzicije, Zadužbina Andrejević, Beograd, 2003.

Elin, Nan: Postmoderni urbanizam, Orion art, Beograd, 2004.

Janić, Miodrag: Upravljanje građevinskim zemljištem u tržišnim uslovima, Jugoslovenski institut za urbanizam i stanovanje - YUGINUS, Beograd, 2004. 
Jevtić, Aleksandar, Grujić Zlatica, Nejgebauer, Jelena: Urbana transformacija Novog Sada, decenija hiperizgradnje i promena, from Trfunović, Veroljub S. Et al: urednik (Editor): Mesto i uloga učesnika u novom zakonu o planiranju i građenju kao i zakonu o državnom premeru i katastru nepokretnosti: zbornik radova sa simpozijuma održanog u julu, 2009 godine, Udruženje urbanista Srbije, Beograd, 2009, 99-108;

Kostreš, Milica: Urbana periferija vojvođanskih gradova (III), Koncept savremenog predgrađa i urbane periferije, DaNS, Novi Sad, 2006, 57:60-61.

Krišanović, Tašana: Studija stanovanja za Generalni plan Novog Sada, JP Urbanizam, Zavod za urbanizam Novi Sad, Novi Sad, 2010.

Milić, Vladimir: Regulacija urbane forme u urbanističkom planiranju - magistarska teza, Univerzitet u Beogradu, Arhitektonski fakultet u Beogradu, Beograd, 1996.

Milić, A. Vladimir: Od abolicije do regeneracije: pretpostavke o budućnosti neformalnih naselja u Srbiji, from Bogdanović, Ružica: urednik: Rekonstrukcija i revitalizacija grada: zbornik radova sa međunarodnog simpozijuma održanog u novembru 2006., Društvo urbanista Beograd, Beograd, 2006, 349-161;

Nađ, Erika: Dobitnici i gubitnici u transformaciji maloprodajne mreže u gradovima centralne i istočne Evrope, from Vujović, Sreten and Petrović, Mina: urednici: Urbana sociologija (Urban Sociology), zavod za izdavanje udžbenika i nastavna sredstva, Beograd, 2005; 362-371.

Pušić, Ljubinko: Urbana politika - deo društvenih promena Sociološki pregled 31.3, 1997, 23336.

Pušić, Ljubinko: Grad bez lica, Mediterran Publishing, Novi Sad, 2009.

Sztompka, Piotr: The Ambivalence of Social Change: Triumph or Trauma?, The Polish Sociological Review, 2000; 3: 275-290

Stzompka, Piotr: Trust and emerging democracy: lessons from Poland, in: Internacional Sociology, 1996b, 11 (1): 37-62;

Tsenkova, Sasha, Nedović-Budić, Zorica: The urban mosaic of post-socialist Europe: space, institutions and policy, Springer, Heidelberg, 2006.

Tsenkova, Sasha: Post-socialist Cities in a Globalizing World, http://80.70.34.228/structu/meurope.nsf/62569fb6fa5eb929c12566e20077b9ba/a886158cb75bffe1c125727a00299068/\$FILE/ développement\%20urbain.pdf, February, 2010. 